\title{
The Effect of Body Pump Training on Bone Density and Balance in Postmenopausal Women with Osteopenia
}

\begin{abstract}
Background and Objective: Bone Density (BD) decreases after menopause; on the other hand, physical activity is a major factor in preventing osteoporosis. The aim of this study was to determine the effects of six-month low-load very high-repetition resistance training (body pump) on $\mathrm{BD}$ and balance in postmenopausal women. Materials and Methods:22 postmenopausal women from Sanandaj City voluntarily participated in the present study (mean age, height, weight and $\mathrm{BMI}=55.2 \pm 1.7 \mathrm{yr}$, $160.8 \pm 3.1 \mathrm{~cm}, 65.1 \pm 3.5 \mathrm{~kg}$ and $25.1 \pm 1.6 \mathrm{~kg} / \mathrm{m2}$ ), and were randomly divided into Resistance Training ( $R T ; n=12$ ) and Control (Con; $n=10)$ groups. The RT performed 3 sessions in week for 6 months, while the control group did not have any regular exercise training during this period. Bone scans (dual energy X-ray absorptiometry) were performed at baseline and after 6 months of training. Also, the balance index was assessed using the Stork Balance Stand Test.

Results: After 6 months, BD in the lumbar spine $(P=0.001)$ and balance $(P=0.001)$ significantly increased in the RT. In addition, there was significant differences in $B D$ of lumbar spine between the RT and control (the lumbar spine: $(P=0.04)$, balance $(P=0.001))$. But after 6 months, there were not any significant changes in femoral neck and forearm (P 0.05)

Conclusion: Six months, low-load very high-repetition resistance training increased the bone density of the lumbar spine while these changes did not occur at the femoral neck and forearm. It seems that the highest impact was on BD of the lumbar spine.

Keywords: Bone mineral density, Balance, Body pump training, Postmenopausal Paper Type: Research Article.
\end{abstract}

Citation (Vancouver): Ahmadi Kakavandi M, Alikhani Sh, Azizbeigi K. The Effect of Body Pump Training on Bone Density and Balance in Postmenopausal Women with Osteopenia. Iran J Health Educ Health Promot. Autumn 2019;7(3): 316-327. [Persian]

Citation (APA): Ahmadi Kakavandi M., Alikhani Sh., Azizbeigi K. (Autumn 2019). The Effect of Body Pump Training on Bone Density and Balance in Postmenopausal Women with Osteopenia. Iranian Journal of Health Education \& Health Promotion., 7(3), 316-327. [Persian]

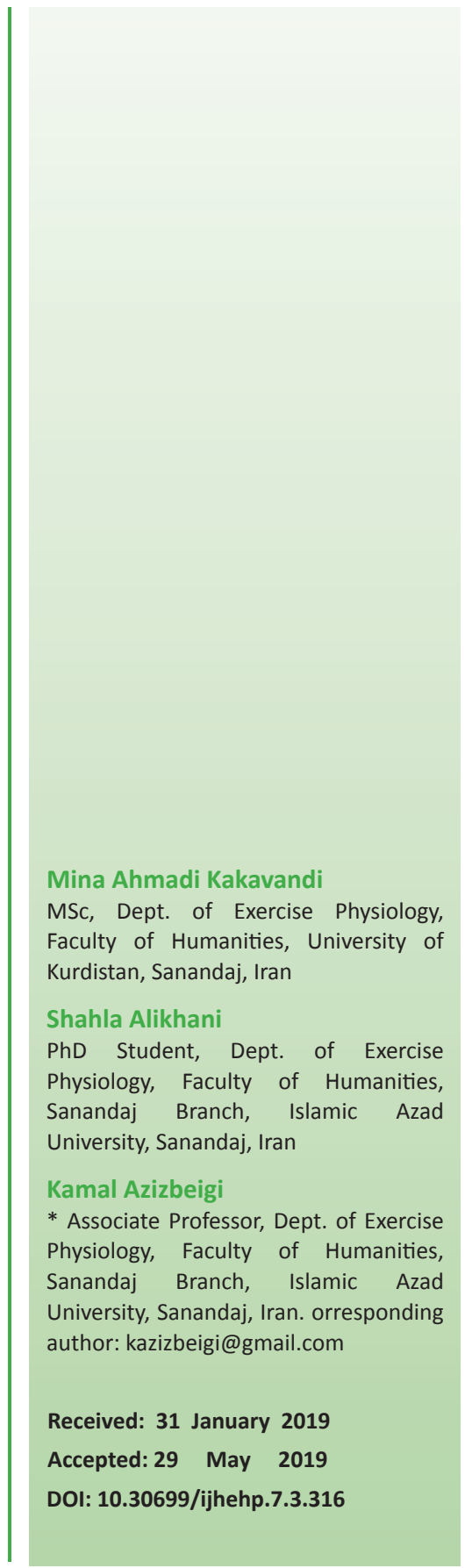


مينا احمدى كاكاوندى

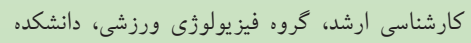
علوم انسانى، دانشكاء كردستان، سنندج، ايران

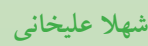

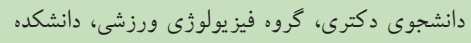

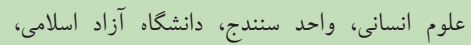
سنندج، ايران كمال عزيزبيخى * دانشيار، كروه فيزيولوزى ورزئي

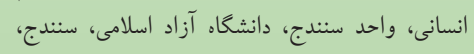
kazizbeigi@gmail.com

$$
\text { ايران. (نو يسنده مسئول): }
$$

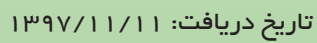

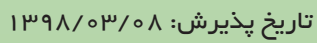

\section{-}

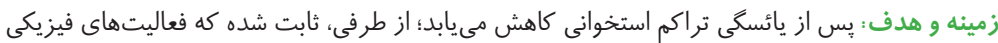

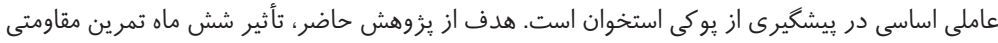

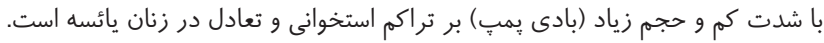

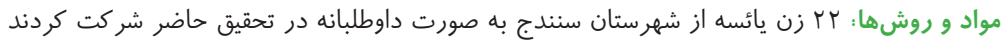

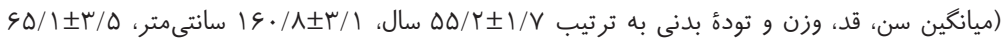

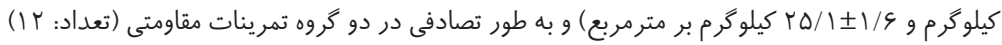

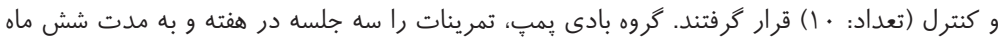

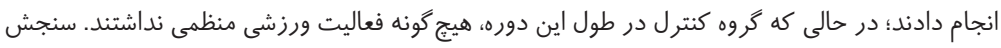

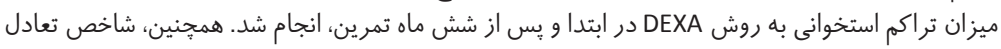

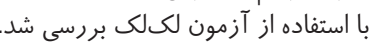

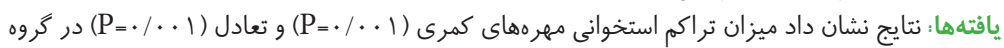

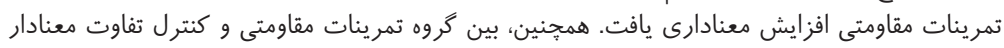

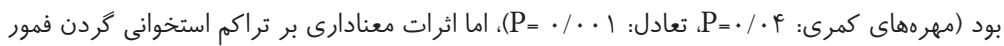

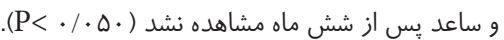

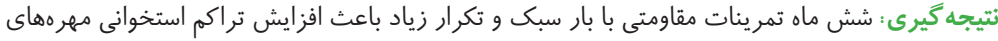

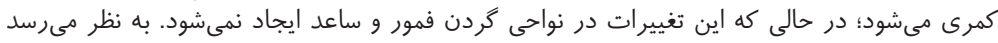

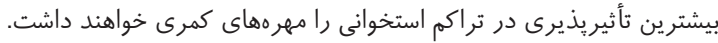

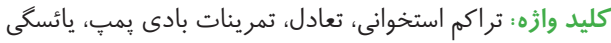

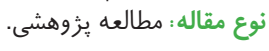

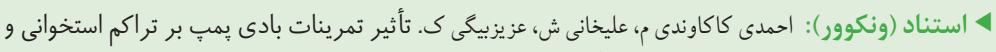

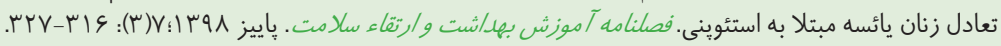

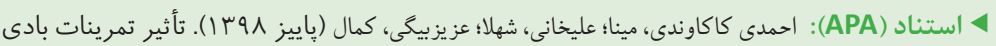

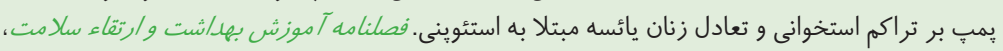


روش ساده، كمهزينه و تأثير گذار بر بهبود بسيارى از بيمارىها

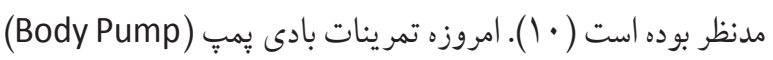

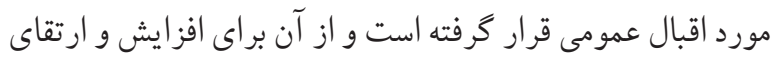
سلامتى استفاده مىشود (11).

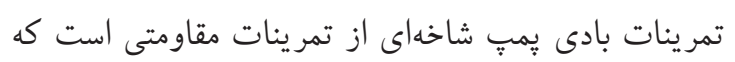

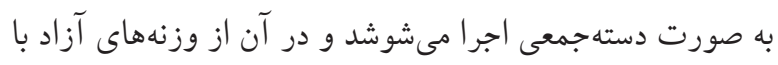

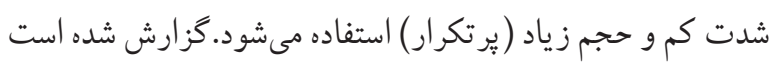

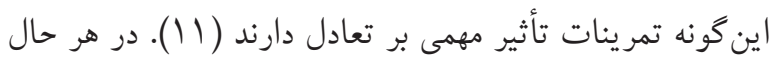

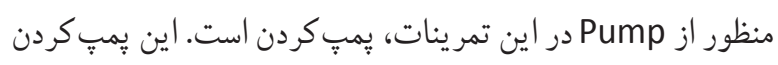

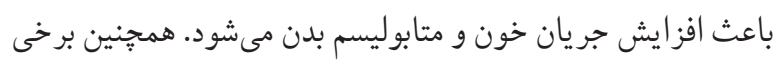

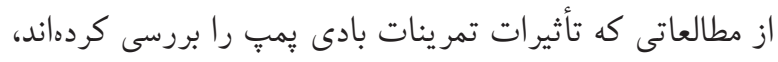

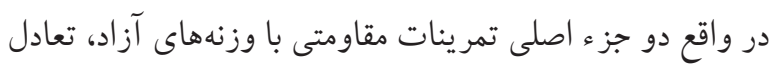
و بار مقاومتى است كه به نظر مىرسد موجب فعالشدن عضلات

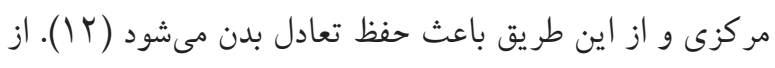

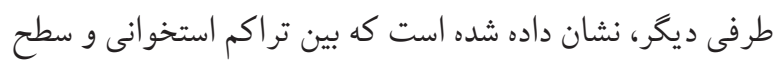

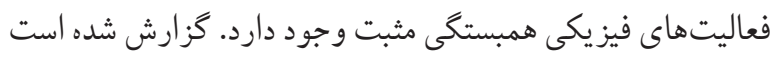

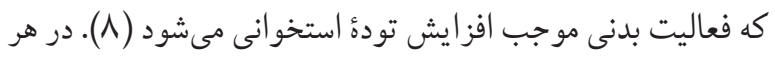
حال تمرينات بادى بمٍ كه همان تمرينات مقاومتى با تكرارهاى

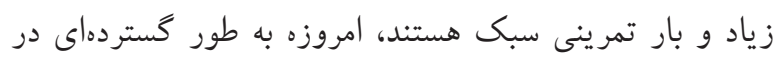

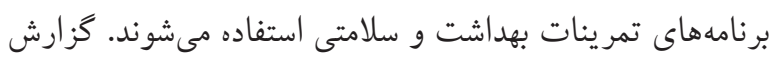
شده است كه اين نوع تمرينات، تأثيرات مطلوبى بر قدرت، تعادل

$$
\text { و عملكرد افر اد مسن خو اهند داشت (I آ). }
$$

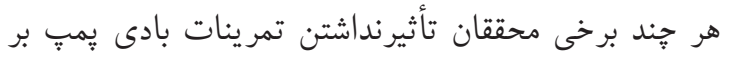

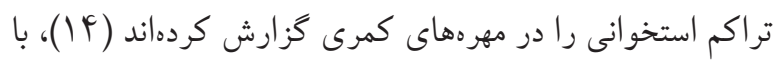

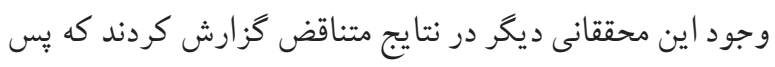

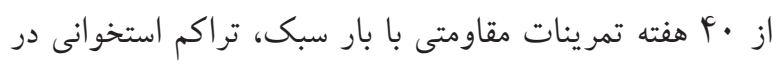

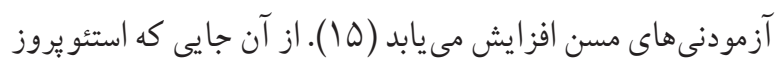

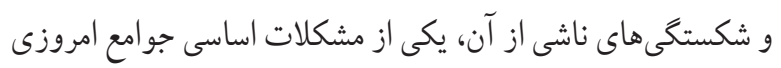

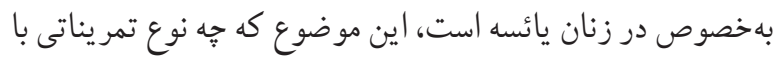

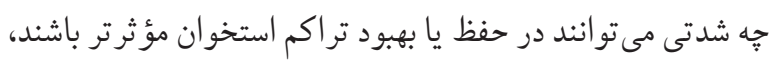
بهدرستى مشخص نشدهاند و تناقضاتى در ادبيات تحقيق مشاهده
ستئويروز يكى از رايج ترين بيمارىهاى متابوليك استخوانى است كه با كاهش تودهٔ استخوان و زوال ميكروساختارى بافت استخوانى

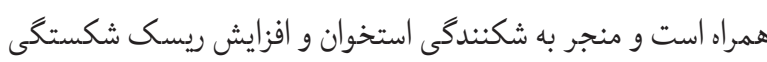

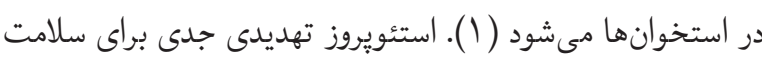
عموم جامعةُ جهانى محسوب مى شود. ريسك شكستكى استخوان

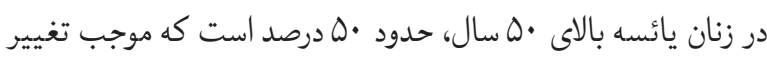

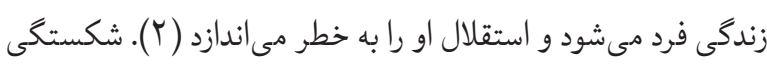
استخوانها ناشى از استئويروز اغلب در مهرهها، كردن استخوان فمور و ناحئ ديستال استخوان راديوس اتفاق مى افتد. شدت و تعداد

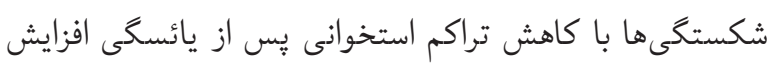

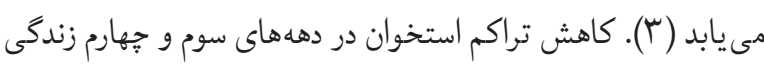

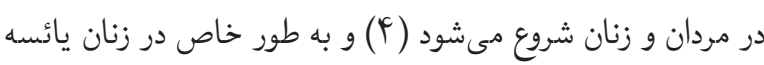

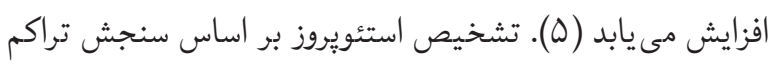

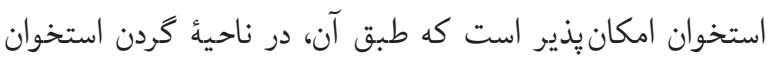

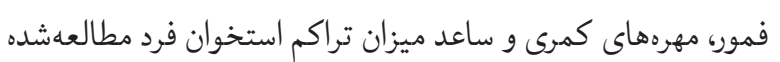

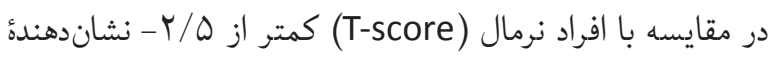
استئوبروز است (9). احتمال وقوع استئويروز در مهرههاى كمرى در

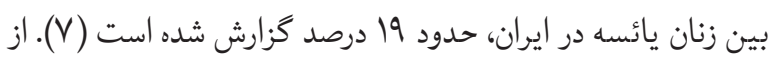

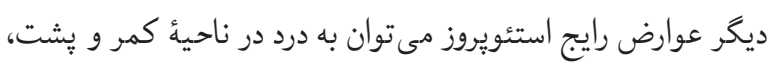
كاهش فعاليتهاى فيزيكى، اختلالات روانى و تغيير شكل ستون فقرات مانند كيفوز اشاره كرد (^).

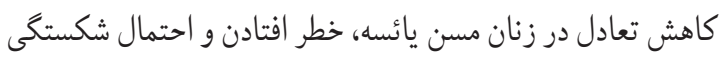
را افزايش مىدهد، لذا بهبود تعادل مى تواند باعث كاهش خطر

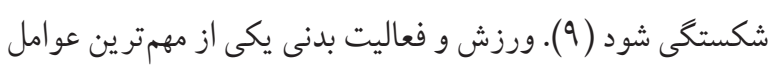

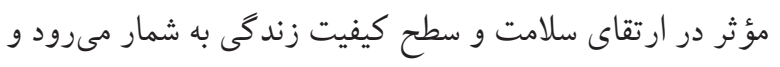

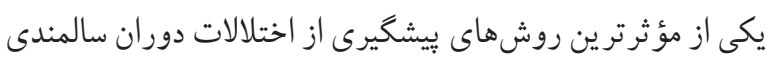

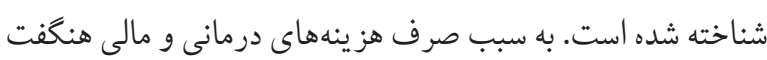

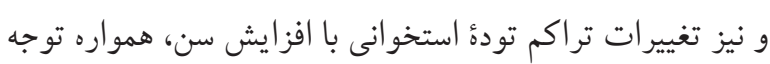

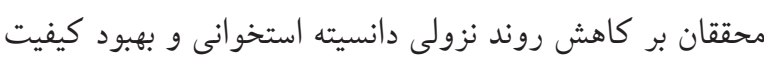

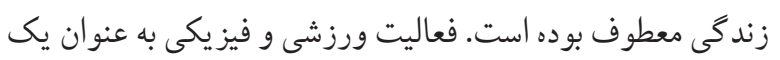




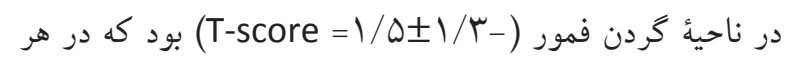

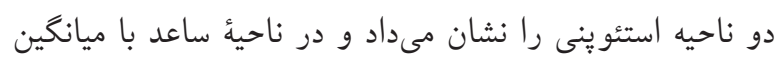

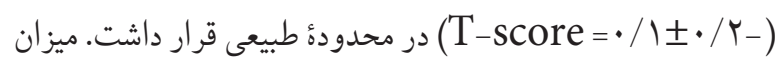
T-score كمتر از إ- تراكم استخوانى نرمال و ميزان T-score

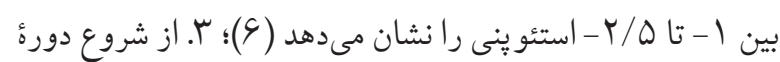

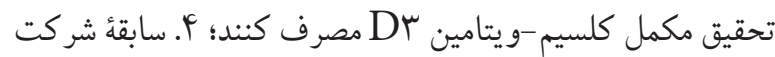
در تمر ينات ورزشى منظم در يك سال گذشته را نداشته باشند؛ و ه. ه.

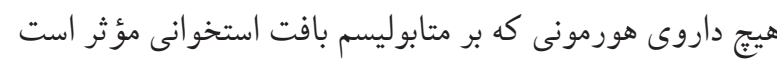

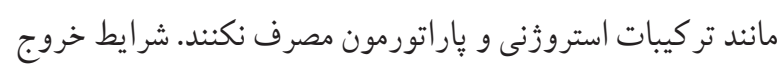

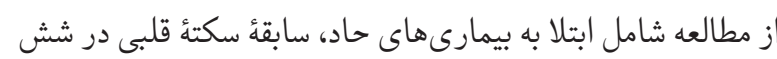

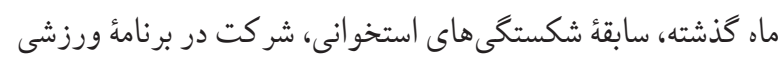

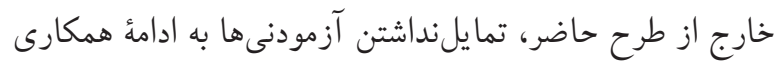
و غيبت بيش از سه جلسه از تمر ينات بود. در ضمن، كروه كنترل

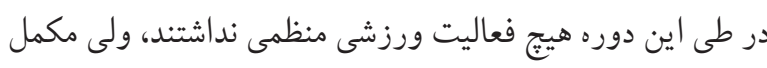

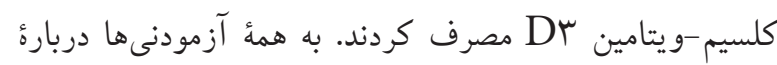

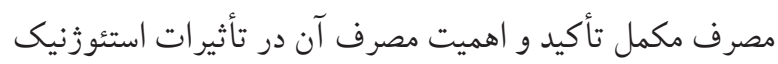

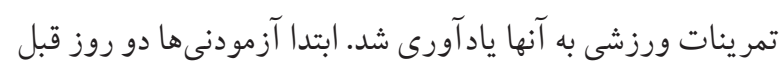

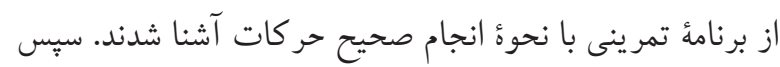

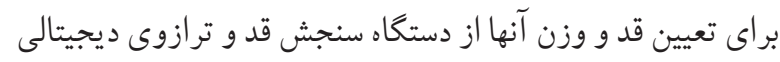
(Germany , Yr. Seca) با تقسيم وزن بر مجذور قد به دست آمد.

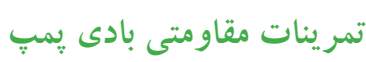

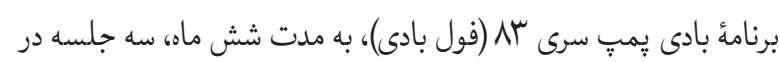

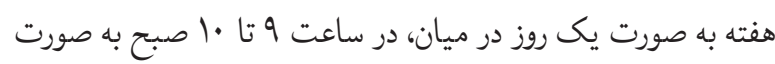

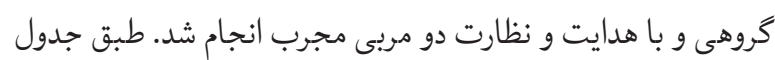

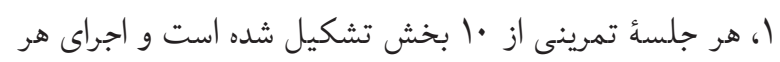

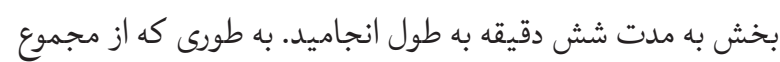

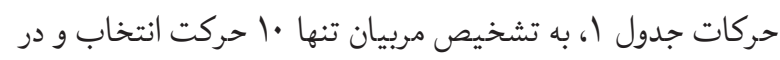

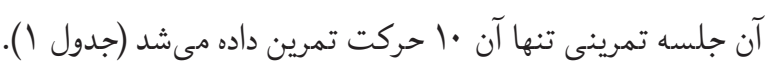

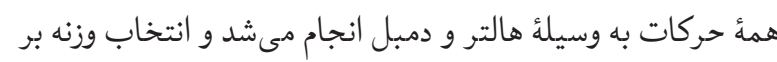

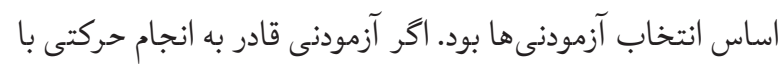

مىشود. بر همين اساس با توجه به محدودبودن مطالعات در زمينهُ

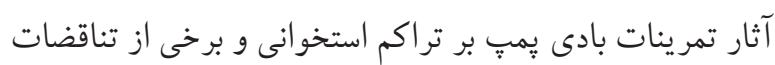

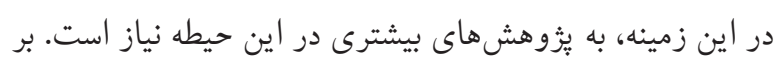

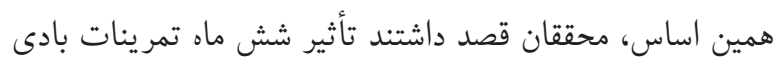

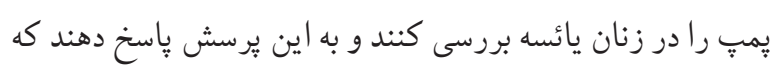

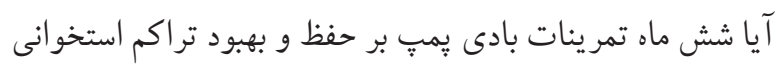

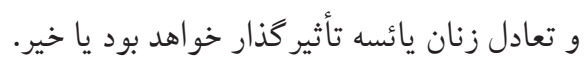
مو اد و روشها آزمودنى هوان مطالعهُ حاضر يك طرح نيمه تجربى به صورت بِيش آزمون و پِّ آزمون

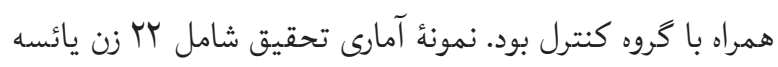

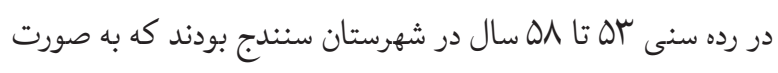
داوطلبانه در تحقيق حاضر شركت كردند و به طور تصادفى در دو

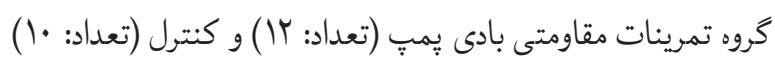

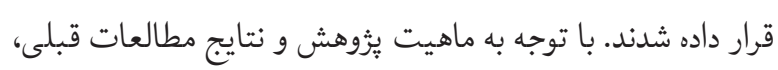

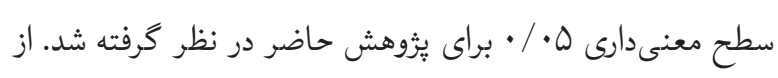

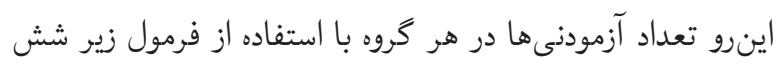

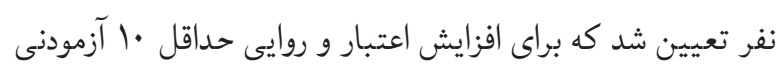
براى هر كروه استفاده شد.

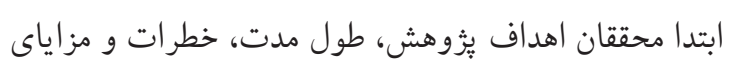

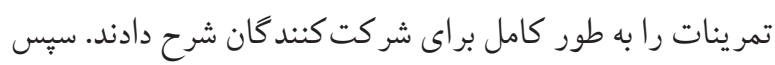

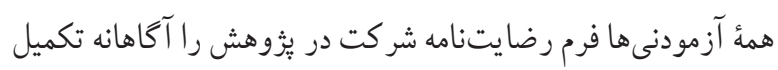

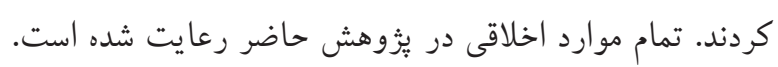

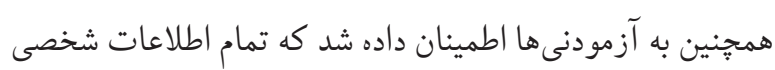

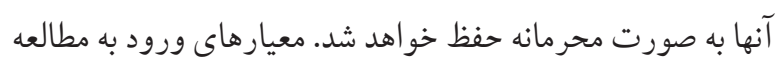
شامل موارد زير بود: ا. حداقل ينج سال از يائسكى آزمودنىها كذشته

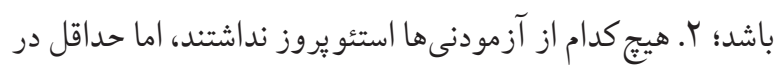
يكى از سه نقطة سنجش تراكم استخوانى (كردن فمور، مهرههاى

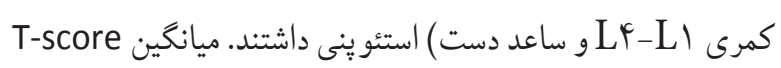
آزمودنى ها در ناحيةٌ مهرههاى كمرى (T-Score 
اندازه گيرى تراكم استخو انى و تعادل

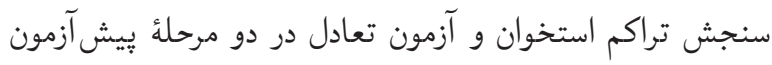

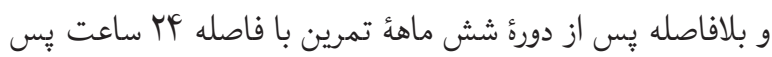

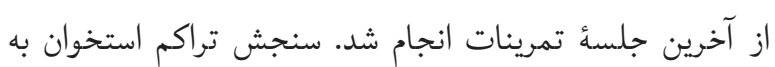
روش جذب اشعهُ ايكس با دو انرزى Dual Energy X-Ray) Absorptiometry (DEXA روشهاى غيرتهاجمى براى بررسى تراكم استخوانى است. اين سنجش ئس است

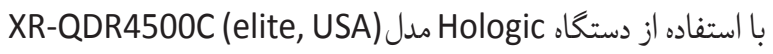

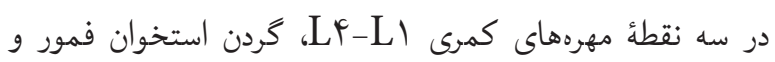
ناحية ساعد انجام شد. براى انجام تست سنجش تراكم استخوانى

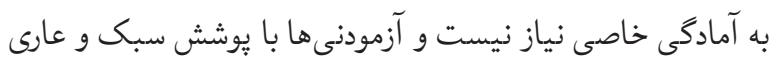

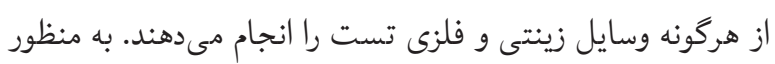

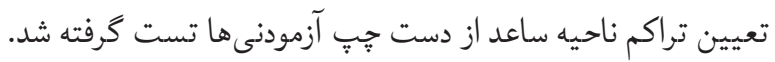

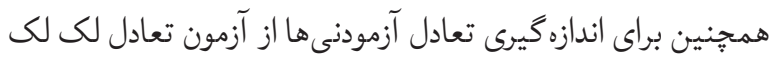
(Stork Balance Stand Test) اجراى صحيح تست به اين صورت است كه فرد روى پإى برتر

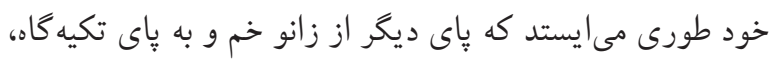

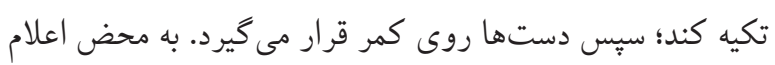

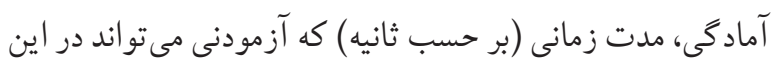

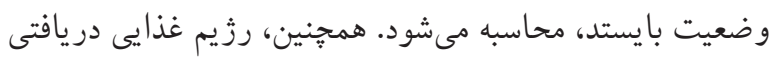
به مدت سه روز قبل از شروع مطالعه و در انتهاى دورءٔ شش ماهه

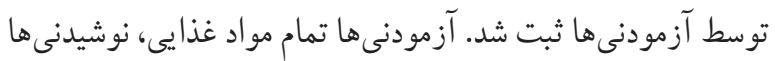

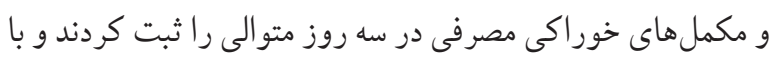

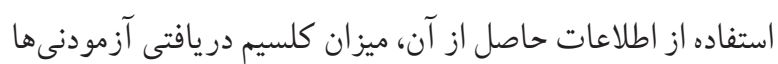
محاسبه شد. تجزيه و تحليل آمارى

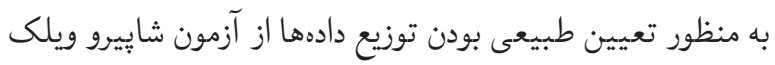

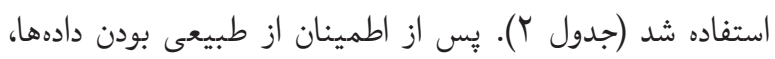

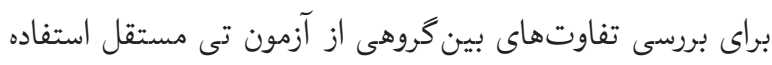

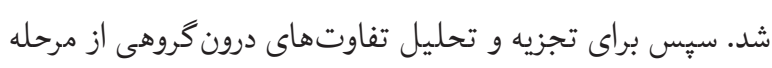

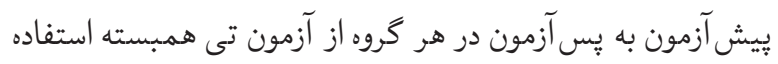

وزنه نبود، با استفاده از جوبهاى سبكتر حركت را شبيهسازى و فقط از وزن بدن خود استفاده مى كرد.

جدول ا. برنامه تمرينى هر جلسة آزمودنىها

\begin{tabular}{|c|c|c|}
\hline 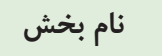 & 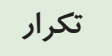 & نام حركت \\
\hline \multirow[t]{7}{*}{ 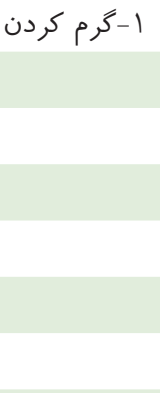 } & rF & 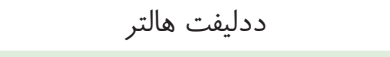 \\
\hline & 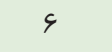 & 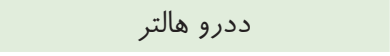 \\
\hline & r & حركت كول و يرس سرشانه با هالتر \\
\hline & 19 & يرس سرشانه با هالتر \\
\hline & r & اسكات \\
\hline & ^ (هر صا) & 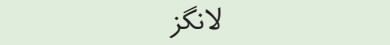 \\
\hline & 19 & جلو بازو هالتر \\
\hline r r-اسكات & $1 \cdot 1$ & اسكات هالتر \\
\hline " ا-سينه & 94 & پرس سينه هالتر \\
\hline \multirow[t]{4}{*}{ 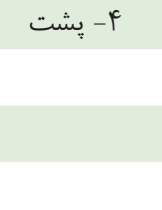 } & $F_{1}$ & ددرو هالتر \\
\hline & 10 & ددليفت هالتر \\
\hline & ir & كلين و يرس با هالتر \\
\hline & $\checkmark$ & پِاور پِرس با هالتر \\
\hline
\end{tabular}

\begin{tabular}{|c|c|c|}
\hline ه- عضله ى سه & rt & يشت بازو ايستاده با هالتر \\
\hline & $\Delta r$ & يشت بازو هالتر خوابيده \\
\hline & r. & يشت بازو تك دمبل نشسته \\
\hline צ- عضله دوسربازو & $\varphi \wedge$ & جلو بازو هالتر \\
\hline \multirow[t]{3}{*}{ V - لانكز ها } & $\Delta$. & اسكات هالتر \\
\hline & 19 & اسكات پرشى \\
\hline & 19 & اسكات ِرشى ضرباندار \\
\hline
\end{tabular}

لانغز هالتر

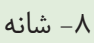
एद بوش آب

\begin{tabular}{|c|c|c|}
\hline & $\wedge$ & نشرخم دمبل \\
\hline & 11 & نشرجانب دمبل \\
\hline & $\wedge$ & كول هالتر \\
\hline & 19 & يرس سرشانه هالتر \\
\hline 9 - عضلات مر كزى & r. & كرانج شكم \\
\hline & If & "يلانك \\
\hline • 1 - سركردن & هر عضله & حر كات كششى يويا \\
\hline
\end{tabular}


در جدول F اطلاعات مربوط به ميانكين و انحراف استاندارد متغيرهاى تحقيق شامل تراكم استخوان در مهرههاى كمرى، استخوان

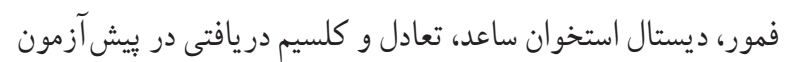
و پِس آزمون به تفكيك در گروههاى مختلف ارائه شده است. نتايج نشان داد در هيجيك از متغيرهاى تحقيق، قبل از شروع مداخله

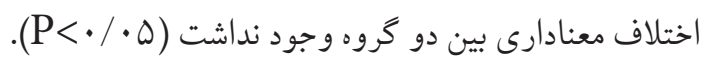
نتايج نشان داد پِ از اجراى تمر ينات، ميزان تراكم استخوان

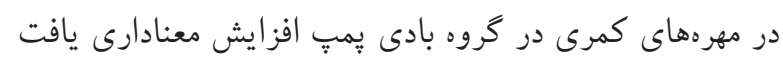
تفاه

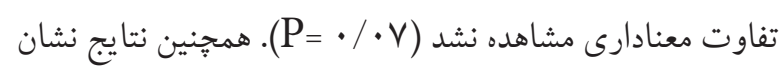
داد بين ميزان تراكم استخوان مهرههاى كمرى در كروه تمرينات

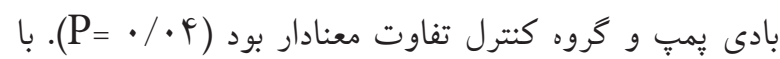

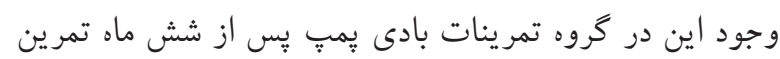

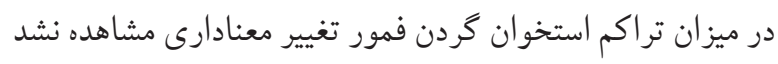

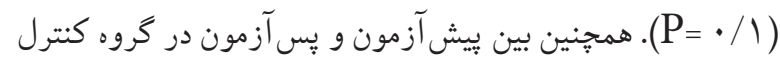

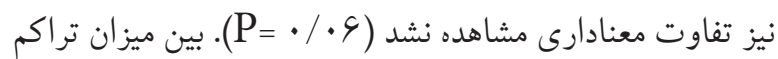

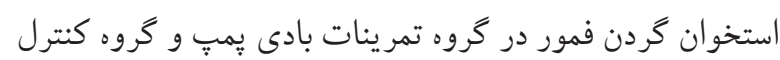

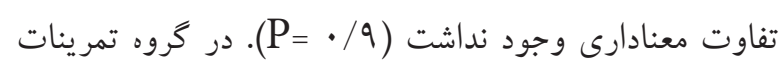

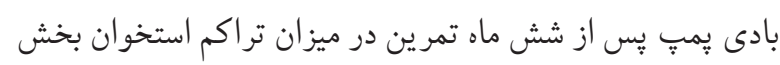

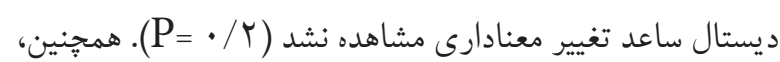
بين ميزان تراكم استخوان ديستال ساعد در گروه آزمايش و كروه كنترل نيز تفاوت معنادارى وجود نداشت (4) • P نتايج نشان داد يس از اجراى تمر ينات، ميزان تعادل آزمودنىها

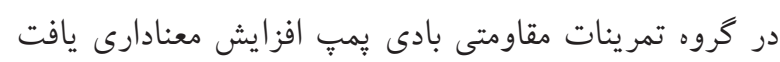

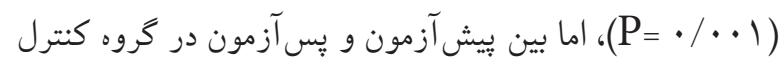

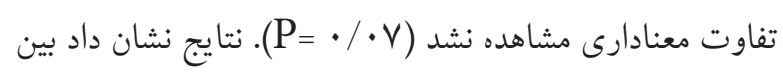

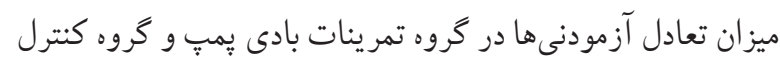

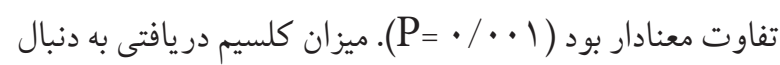
مصرف مكمل كلسيم بس از شش ماه در هر دو گروه آزمايش و و

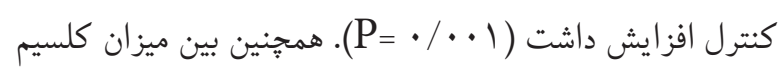

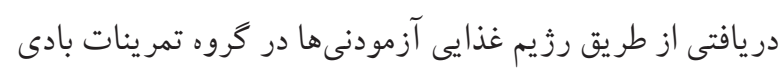

شد. تمامى تحليلهاى آمارى در سطح معنادارى ه• / • و با استفاده از نرمافزار SPSS (Lservrc)

جدول r. نتايج آزمون شايِيرو ويلك دربارةٔ متغيرهاى تحقيق

\begin{tabular}{|c|c|c|c|}
\hline يִس آزمون & بيش آزمون & كروه & متغير \\
\hline.$/ 94$ & $\cdot / 11$ & بادى بمٍٍ & \multirow{2}{*}{ مهر ههاى كمرى } \\
\hline . & $\cdot / r q$ & كنترل & \\
\hline . /Dr & $\cdot / F F$ & بادى بمِ & \multirow{2}{*}{ گردن فمور } \\
\hline$\cdot / \mu$ & 每/ & كنترل & \\
\hline .190 & $\cdot / \mathrm{V}^{\mathrm{F}}$ & بادى يمب & \multirow{2}{*}{ ديستال ساعد } \\
\hline.$/ 19$ & $\cdot / r 1$ & كنتر ل & \\
\hline$\cdot / r$ & $\cdot / \mu F$ & بادى يمب & \multirow{2}{*}{ تعادل } \\
\hline.$/ 49$ & . & كنترل & \\
\hline$\cdot / \mu 1$ & $\cdot / T \Delta$ & بادى بمب & \multirow{2}{*}{ كلسيم دريافتى } \\
\hline$\cdot|r|$ & $\cdot / f$ & كنترل & \\
\hline$\cdot / 9 r$ & $\cdot 19 V$ & بادى بمب & \multirow{2}{*}{ اسكات } \\
\hline .199 & .119 & كنترل & \\
\hline.$/ 9 V$ & 每 & بادى يمب & \multirow{2}{*}{ ددليفت } \\
\hline$\cdot / 4$ & $\cdot / 1$ & كنترل & \\
\hline
\end{tabular}

يافته هـا

نتايج ويثگى هاى توصيفى و فيزيولوزيكى آزمودنى ها در جدول ب

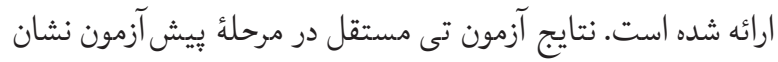
داد بين ميانگين سن، قد، وزن و تركيب بدنى دو گرووه كنترل و و

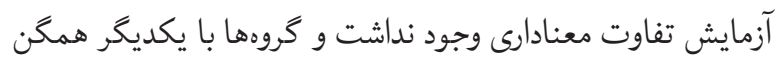

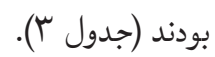

جدول سّ. ويخگى هاى جسمانى آزمودنى ها در ابتداى يخوهش

\begin{tabular}{|c|c|c|c|c|}
\hline P-value & $\mathbf{t}$ & $\begin{array}{c}\text { كنترل } \\
\text { Mean } \pm S D\end{array}$ & 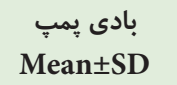 & متغير \\
\hline$\cdot / 1$ & $1 / r \mu$ & $\Delta \Delta / \wedge \cdot \pm|/ \varsigma|$ & $\Delta F / \Lambda H^{\prime} \pm I / V F$ & سن (سال) \\
\hline$\cdot / \pi$ &.$/ 9 r$ & 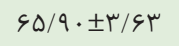 & $\varepsilon F / \Delta \cdot \pm r / F V$ & وزن (كيلوگرم) \\
\hline .19 & $\cdot / F F$ & $|\varepsilon| / r \cdot \pm r / \cdot \Lambda$ & $19 \cdot / \Delta \Lambda \pm \mu / \mu r$ & قد (سانتى متر ) \\
\hline.$/ 4$ &.$/ 4 s$ & $r \Delta / r V \pm 1 / V$ & $r \Delta / \cdot r \pm 1 / V$ & $\begin{array}{c}\text { بر متر مربع) BMI } \\
\text { (كيلوم) }\end{array}$ \\
\hline
\end{tabular}


تغييرات تراكم استخوان مهرههاى كمرى در گروه تمرينات بادى

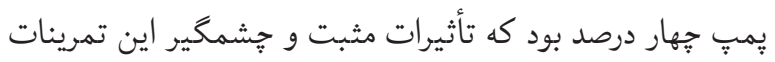
را در اين ناحيه حساس نشان مىدهد. اجراى حركاتى مانند ددليفت، ددرو و حركت كرانج كه براى تراكم استخوانى مهرههاى كمرى مفيد هستند، از طريق اعمال بارمكانيكى مناسب در ناحئ مهرههاى بردي كمرى اثرات استئوزنيك ايجاد مى كند و همزمان با مصرف مكمل

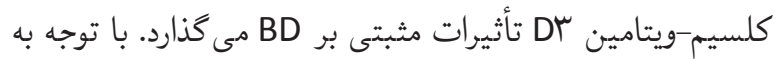
اينكه براى ايجاد اثرات استئوزنيك بر تراكم استخوانى به دورههاى

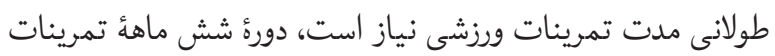

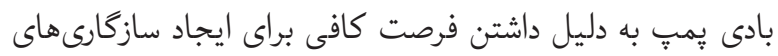
بافت استخوانى به افزايش معنادار BD در مهرههاى كمرى و حفظ و تثبيت تراكم استخوانى در نواحى گردن فمور و ساعد منجر مى شود.

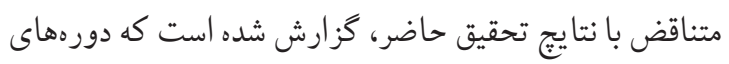

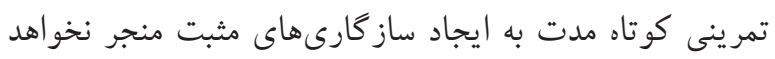
شد. محققان كزارش كردند شش هفته تمرينات مقاومتى تأثير مدري مثبى بر تراكم استخوانى زنان يائسه در سه ناحئ مهرههاى كمرى،

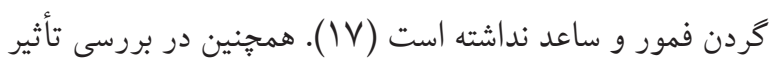

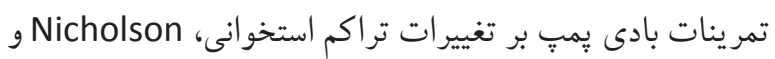

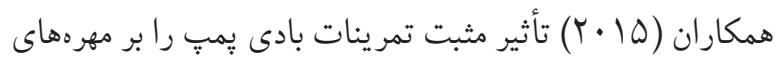

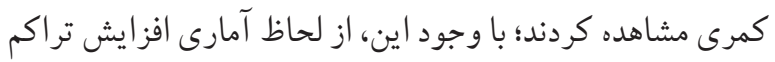

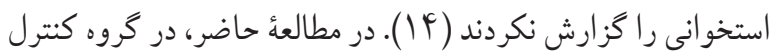

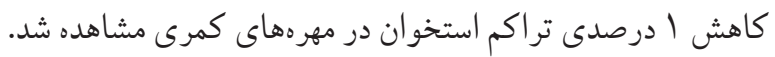

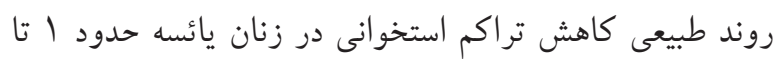

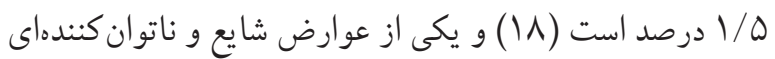

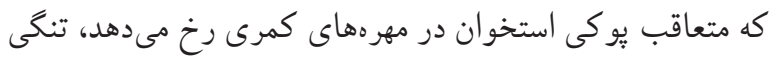

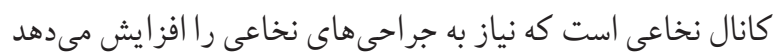

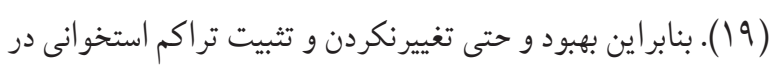

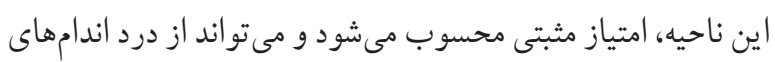

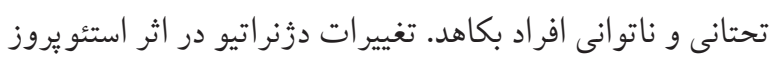

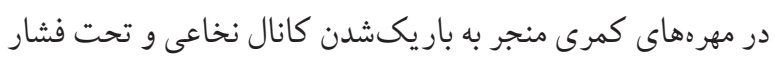
قراركرفتن اعصاب و عروق خونى آن مىشود ( • ب) كه مشكلات

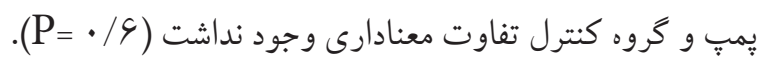

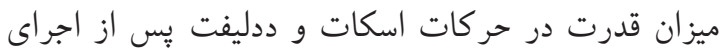

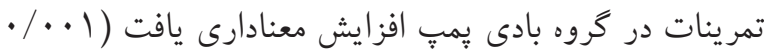

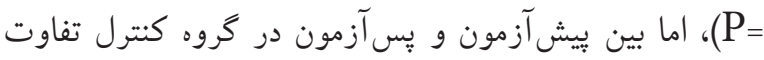

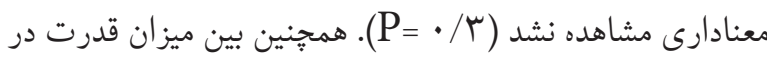

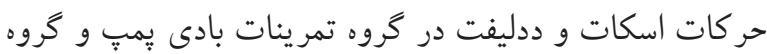

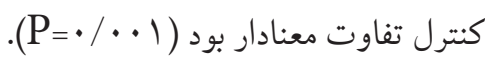

جدول ⿷匚. تغييرات متغيرهاى تحقيق يس از شش ماه تمرين

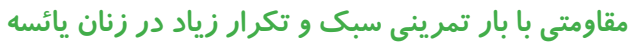

\begin{tabular}{|c|c|c|c|}
\hline $\begin{array}{c}\text { يس آزمون } \\
\text { Mean+SD }\end{array}$ & $\begin{array}{c}\text { بيش آزمون } \\
\text { Mean士SD }\end{array}$ & 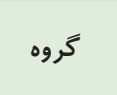 & متغير \\
\hline$\dagger * / 19 \cdot \pm . / \cdot \Delta$ & $\cdot / \Lambda \Delta S \pm \cdot / \cdot \varphi \varphi$ & بادى يمٍ & مهر ههاى كمرى \\
\hline$\cdot / \Lambda F s \pm \cdot / \cdot F V$ & $\cdot / \Lambda F \vee \pm . / . F V$ & كنترل & $(\mathrm{gr} / \mathrm{cmr})$ \\
\hline$\cdot / \nabla \cdot \Delta \pm \cdot / \cdot \Delta q$ & $\cdot / V \cdot \varphi \pm \cdot / \cdot \Delta q$ & بادى يمب & كردن فمور \\
\hline$\cdot / \mathrm{A} \cdot \varsigma \pm \cdot / \cdot \Delta \Lambda$ & $\cdot / \vee \cdot \Lambda \pm \cdot / \cdot \Delta \Lambda$ & كنترل & $(\mathrm{gr} / \mathrm{cmr})$ \\
\hline
\end{tabular}

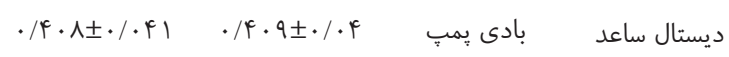
كنترل (gr/cmr)

بادى يمب

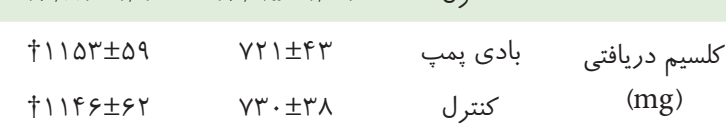

\begin{tabular}{|c|c|c|c|}
\hline $\begin{array}{c}\dagger * 9 \pm 1 / 0 \\
r \pm 1\end{array}$ & $\begin{array}{l}r \pm 1 / 0 \\
r \pm 1\end{array}$ & بادى يم" & اسكات (kg) \\
\hline $\begin{array}{c}\dagger * V \pm 1 / 0 \\
r \pm 1\end{array}$ & $\begin{array}{c}\mu \pm 1 / 0 \\
r \pm 1\end{array}$ & بادى يم" & ددليفت (kg) \\
\hline
\end{tabular}

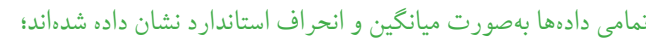

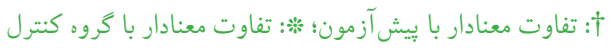

بحث هدف مطالعه حاضر بررسى تأثير شش ماه تمرينات بادى بِمٍ سرى

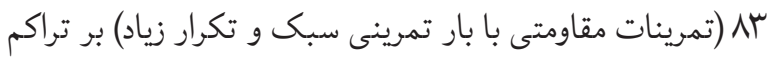

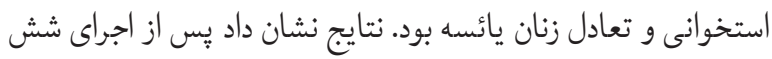

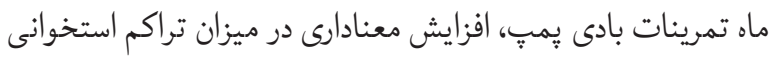
مهرههاى كمرى در آزمودنىهاى گروه تمرينى مشاهده شد. ميزان 
بر اين ناحيه بهتر است حر كات تمرينى ويزماى براى ناحية هيب

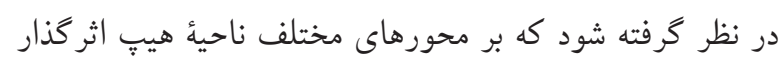

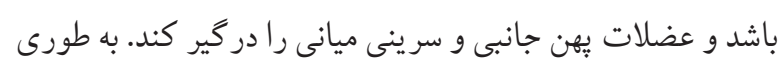

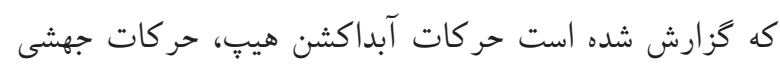

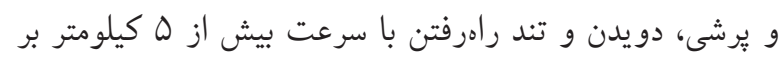

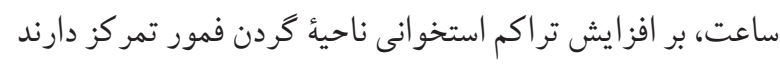

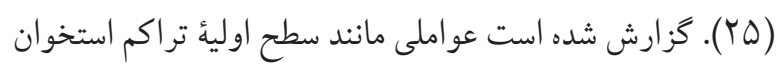

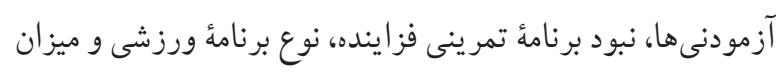

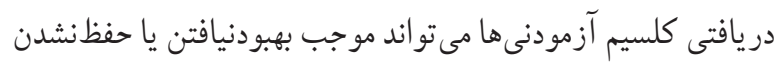

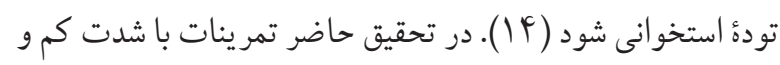
تكرار زياد انجام شد. به نظر مىرسد مهم ترين عامل تأثيرنداشتن،

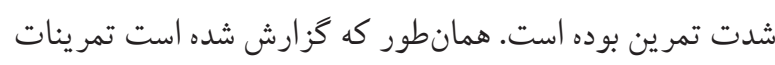

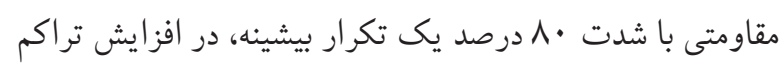

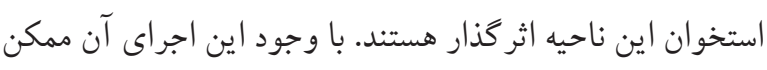

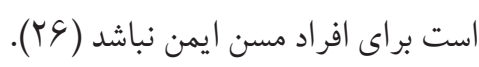

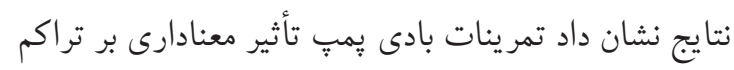

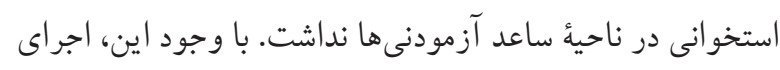
تمر ينات موجب حفظ تراكم استخوانى در ناحئ ساعد شد كه احتمالاً

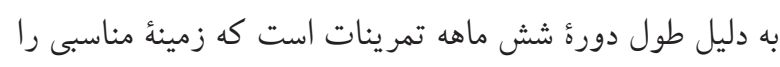

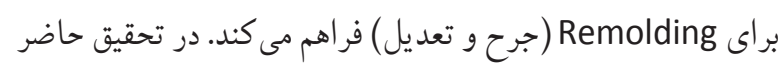

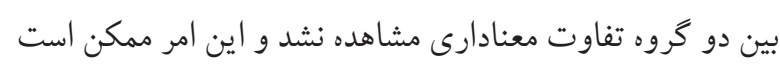

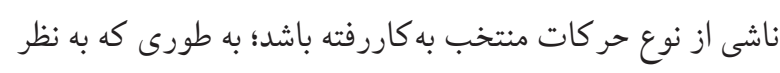

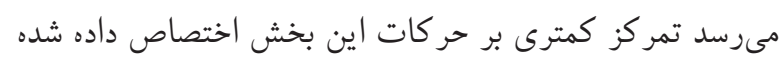

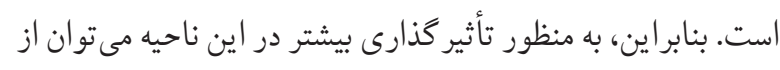

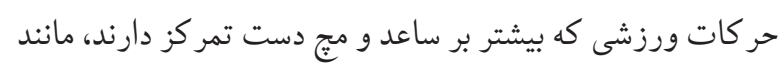

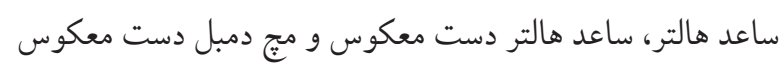

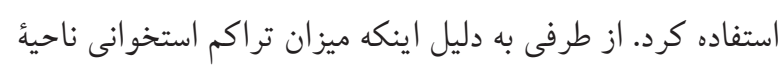

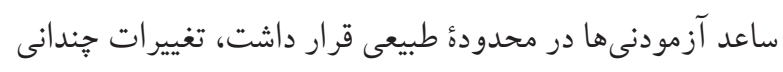

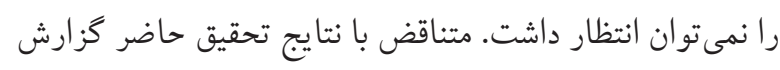

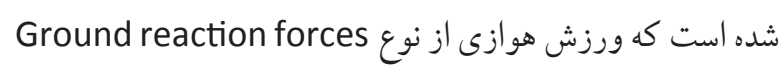

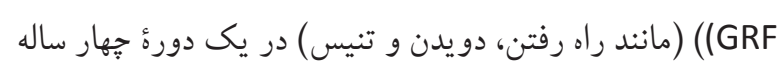

فراوانى را براى افراد به همر اه دارد. دليل ناهمخوانى اين مطالعه

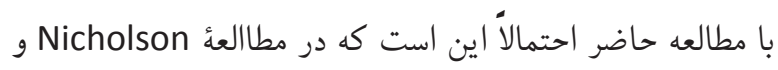

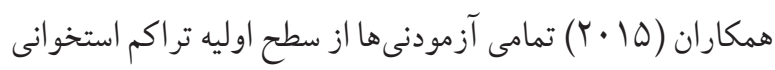

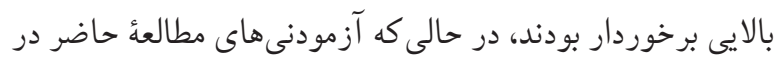
اين ناحيه دجار استئو بنى بودند.

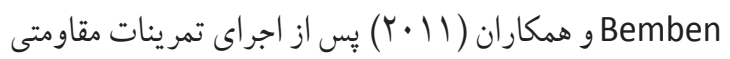

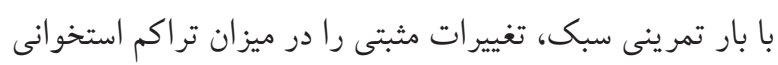

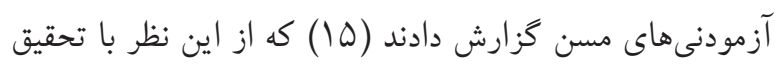

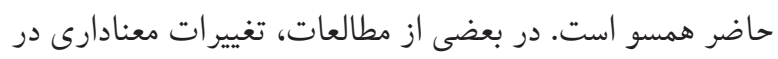

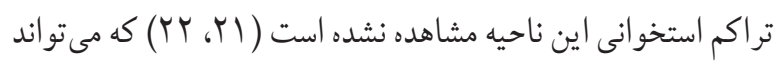

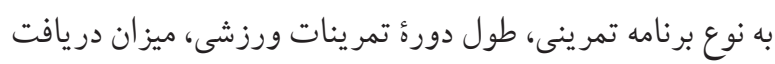

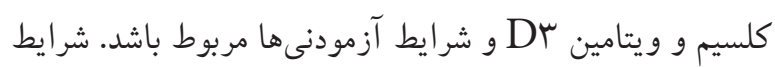

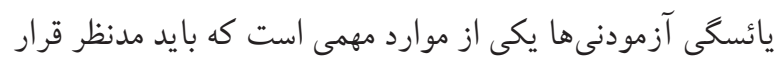

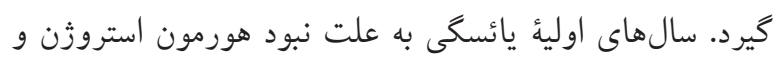

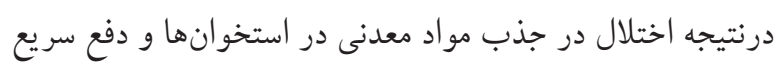

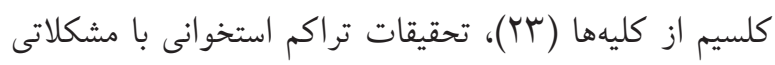

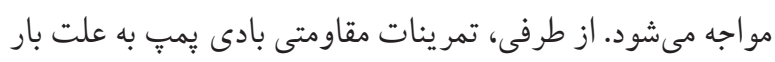

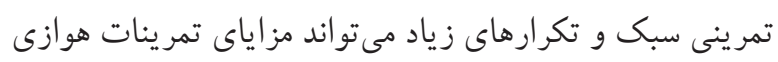

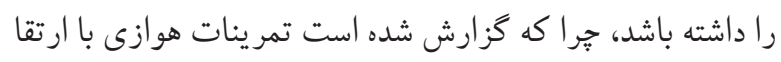

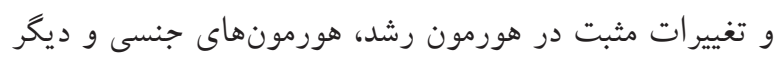

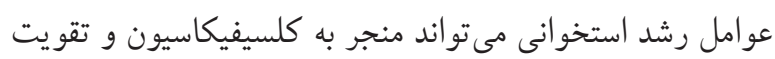
استخوانها شود (YF). (MF) نتايج نشان داد ميزان تراكم استخوانى در ناحيه كردن استخوان

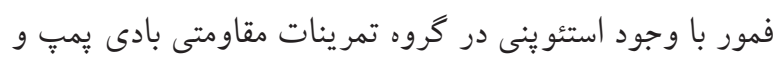

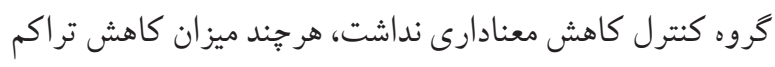
استخوانى دركروه بادى بمب كمتر بود. كاهش كمتر تراكم استخوان

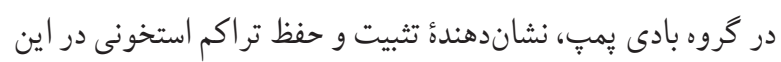

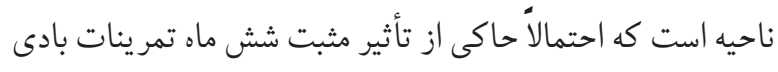

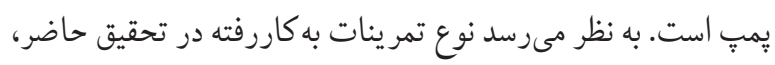

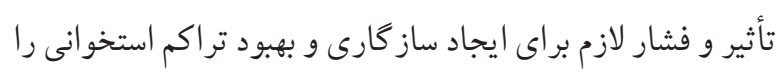

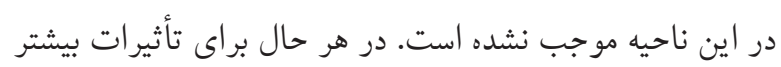


تأثير آن بر شاخصهاى متابوليكى استخوانى و اهميت بيشخيرى از استئو يُروز مىتوان كفت كه تمرينات ورزشى منظم مى بواند

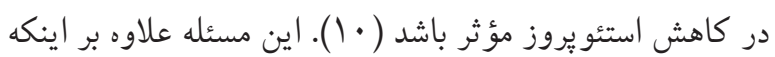
در زمينهُ بيشكيرى از تحليل تراكم استخو انى مؤثر است، احتمالاً

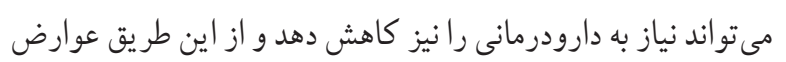

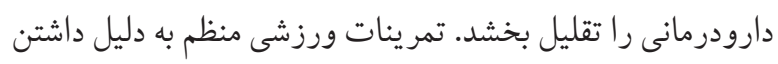

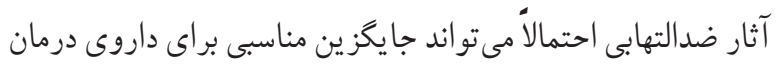
جايغز ينى هورمون (Hormone replacement treatment) (استروزن و بِروزسترون) باشد كه جز ء داروهاى درمان استئو يُووز

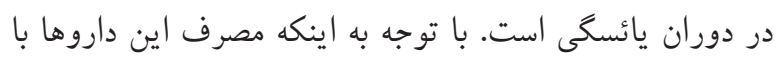

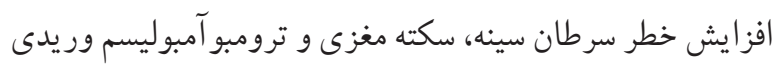

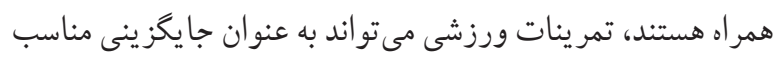

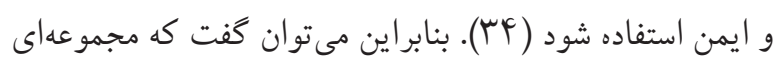

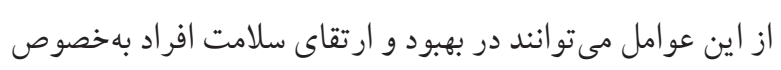
زنان يائسه مؤثر باشند.

از طرفى، با توجه به اينكه تعامل عوامل فعاليت فيزيكى و باسل تغذيه، عوامل هو رمونى و رشدى در متابوليك استخوانى تأثير كذار

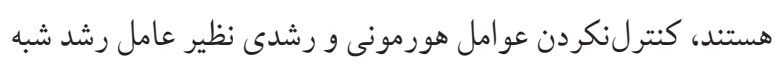

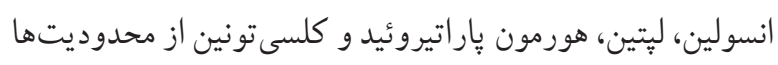

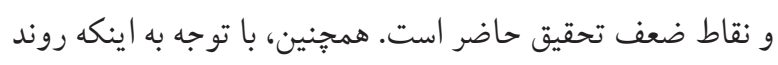

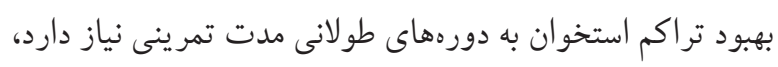

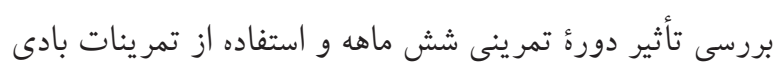
يمب از نقاط قوت و نو آورانهُ تحقيق حاضر است. نتيجاه كيرى

با توجه به نتايج تحقيق حاضر، پِ إس از شش ماه تمرينات مقاومتى

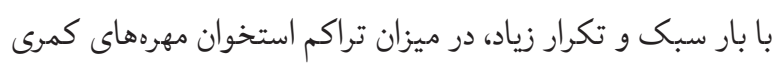

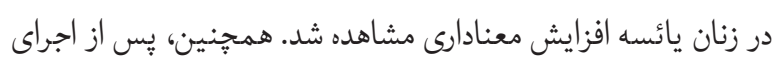
اين تمرينات ميزان تراكم استخوان در ناحية كردن استخوان فمور و ديستال استخوان ساعد به طور نسبى حفظ شد و نسبت به گرووه كنترل روند كاهشى كمترى داشت. در اين خصوص مى توان اظهار

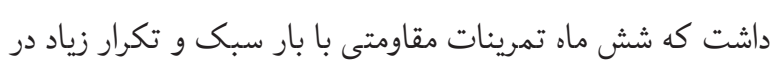

و به صورت سه روز در هفته، روند كاهش BD در ناحية ساعد

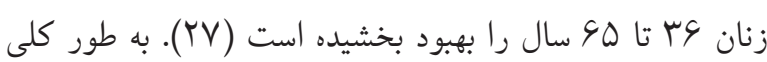

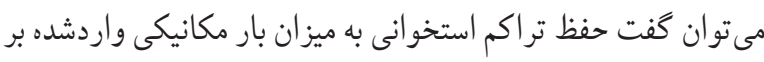

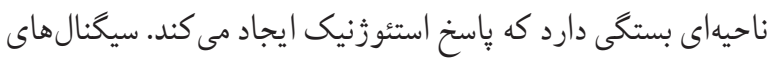

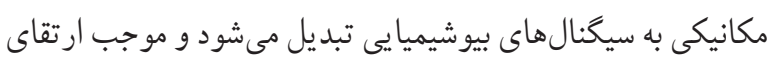

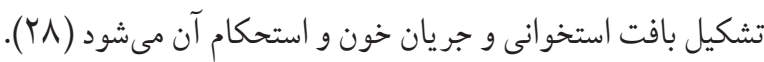

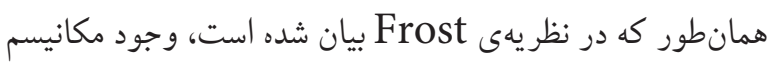

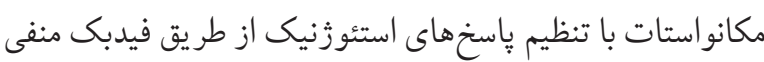

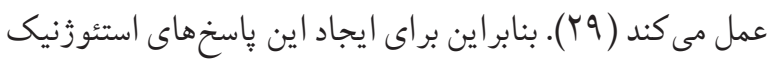
لازم است شدت تمرينات ورزشى بيش از حد آستانه باشد ( • (ץ).

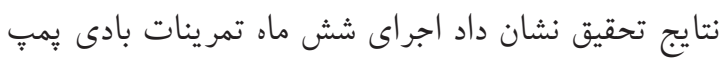
باعث افزايش معنادار تعادل در زنان يائسه مى شود كه يكى از

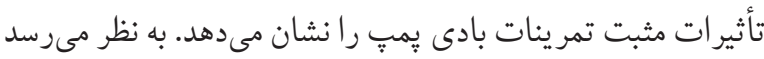

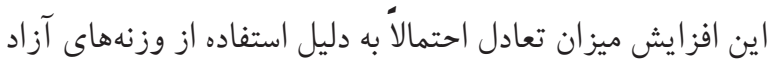
است. تقو يت عضلات مركزى و عضلات اندام تحتانى نيز نقش مهمى إنى

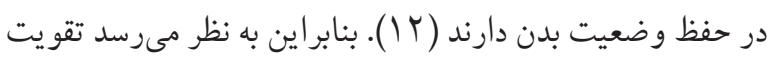

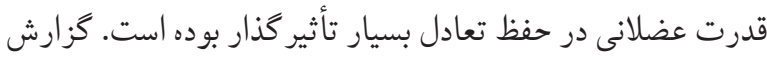

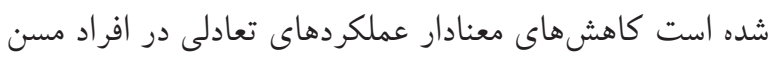

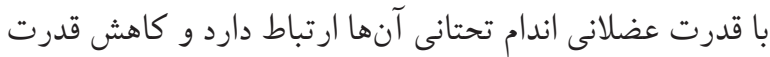

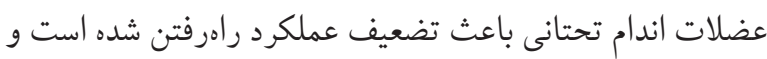
خطر افتادن فرد را افزايش مىدهد (آ⿱艹). مطالعات ديكر نشان

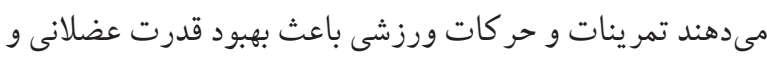

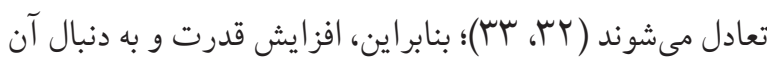
افزايش تعادل آزمودنىها در اثر تمرينات ورزشى اهميت زيادى دادي دارد.

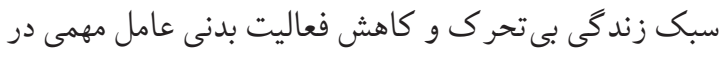
تسريع روند تحليل BD است. در مقابل، فعاليت بدنى براى جلو گيرى از كاهش، حفظ و افز ايش تراكم توده استخوانى بيشنهاد مى شود. با اين وجود، در دهههاى اخير محبوبيت انجام فعاليتهاى ورزشى إنى

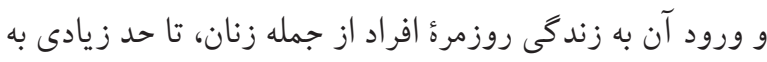
يُيشكيرى و درمان اين اييدمى خاموش كمى كرده است ( • (1).

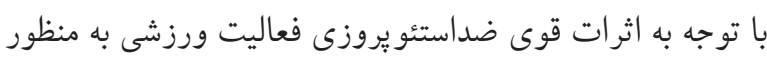


اينكه استئو بر روز نوعى بيمارى خاموش است و تا رسيدن به مراحل

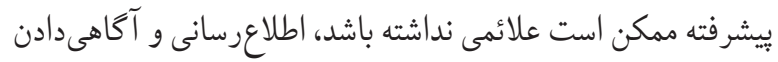

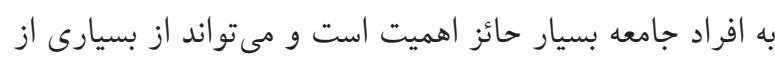

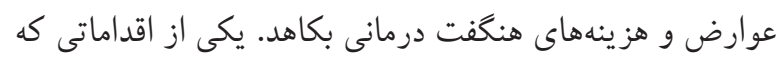

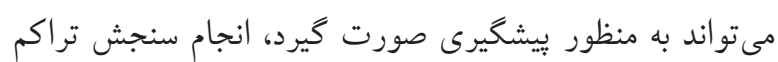

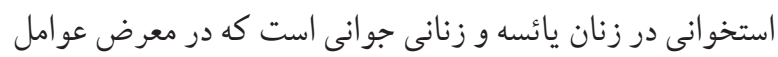

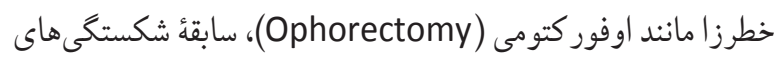
خودبهخود و درمانهاى طولانى مدت با كورتيكو استروئيدها قرار

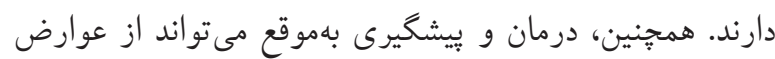

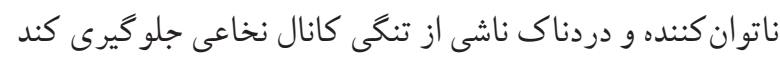
و باعث بالارفتن سطح كيفيت زندكى و ارتقاى سلامت آنان شود. تقدير و تشكر باعت بالارفن سطن نويسندكان مراتب تشكر و قدردانى خود را از آزمودنى هاى محترم و تمام افرادى كه در تحقيق حاضر همكارى كردند، ابراز مى دارند.

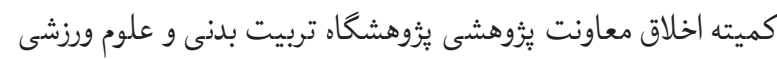
اين تحقيق را با كد IR.SSRC.REC.1397.013 تأييد كرده است.

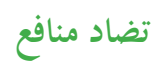
بين نويسندگان هيج گونه تعارضى در منافع خاب اين مقاله وجود ندارد.

\section{References}

1. Cesarec G. Effect of Exercises on Quality of Life in Women With Osteoporosis and Osteopenia. Collegium Antropologicum. 2014; 38(1):247-254.

2. Watts NB. Postmenopausal Osteoporosis: A Clinical Review. Journal of Women's Health. 2018; 27(9):1093-1096. https://doi.org/10.1089/jwh.2017.6706 PMid:29583083

3. Goyal M, Kumar A, Moitra M, Pathania A. Effect of Back Extension Exercise on Quality of Life and Back Extensor Strength of Women With Osteoporosis. Journal of Exercise Science and Physiotherapy. 2013; 9(2):113. https://doi.org/10.18376//2013/v9i2/67563

4. Melton lii L, Khosla S, Atkinson E, O'connor M, O'fallon W, Riggs B. Cross-Sectional Versus Longitudinal Evaluation of Bone Loss in Men and Women. Osteoporosis International. 2000; 11(7):592-599. https://doi.org/10.1007/s001980070080
بهبود و تثبيت ميزان تراكم استخوان در زنان يائسه تأثير بسزايى دارد. همجنين با توجه به اينكه اين تمرينات باعث افزايش قابل توجه تعادل در آزمودنىها شده است، مى توان از اين تمرينات به منظور بهبود، حفظ و تثبيت تراكم استخوانى، افزايش تعادل و كاهش خطر افتادن و شكستگى هاى ناشى از آن در افراد مسن، بهخصوص در زنان، بهره برد و به عنوان روشى ييشخيرانه در زمينه ييشخيرى از آسيبهاى جدى ناشى از استئويروز از قبيل شكستخى هاى استخوانى مورد توجه قرار گيرد. اين موضوع يكى از عوامل بسيار مهم در بهبود و ارتقاى سلامت زنان به شمار مى آيد. همجنين، به منظور پيشخيرى از بيمارىها و بهبود و ارتقاى سلامت زنان علاوه بر فعاليتهاى ورزشى منظم، ضرورى است عادات تغذيهاى نامناسب نيز اصلاح شود؛ مانند ترك سيگار، اجتناب از مصرف زياد قهوه، جاى، نمك، نوشابهای گازدار، مصرف كافى كلسيم-ويتامين D و تا حد امكان خوددارى از مصرف داروهايى كه منجر به كاهش تراكم استخوانى مى شوند مانند كلوكوكورتيكوييدها. بنابراين مىتوان كفت كه تمرينات مقاومتى با شدت كم و تكرار زياد مانند تمرينات بادى يمبٍ تحقيق حاضر، مى توانند در برنامهُ درمانى استئو يروز زنان يائسه و نيز در زنان جوان به عنوان عامل مهمى در سلامت استخوانها به كار گرفته شوند. با توجه به

5. Warming L, Hassager C, Christiansen C. Changes in Bone MineralDensityWithAgeinMenandWomen:ALongitudinal Study. Osteoporosis International. 2002; 13(2):105-112. https://doi.org/10.1007/s001980200001 PMid:11905520

6. Cosman F, De Beur S, LeBoff M, Lewiecki E, Tanner $B$, Randall $S$, et al. Clinician's Guide to Prevention and Treatment of Osteoporosis. Osteoporosis International. 2014; 25(10):2359-2381. https://doi.org/10.1007/s00198-014-2794-2 PMid:25182228 PMCid:PMC4176573

7. Irani AD, Poorolajal J, Khalilian A, Esmailnasab N, Cheraghi Z. Prevalence of Osteoporosis in Iran: A Meta-Analysis. Journal of Research in Medical Sciences: The Official Journal of Isfahan University of Medical Sciences. 2013; 18(9):759.

8. Dhillon V, Hurst N, Hannan J, Nuki G. Association of Low 
General Health Status, Measured Prospectively by Euroqol EQ5D, With Osteoporosis, Independent of a History of Prior Fracture. Osteoporosis International. 2005; 16(5):483-9. https://doi.org/10.1007/s00198-004-1705-3 PMid:15875094

9. Karinkanta S, Piirtola M, Sievänen H, Uusi-Rasi K, Kannus P. Physical Therapy Approaches to Reduce Fall and Fracture Risk Among Older Adults. Nature Reviews Endocrinology. 2010; 6(7):396. https://doi.org/10.1038/nrendo.2010.70 PMid:20517287

10. Bottaro MF, Reis VM, Oliveira R, Bezerra L, Abdhala L, Lima $\mathrm{RM}$, et al. Effect of Yoga on Bone Metabolism in PostMenopausal Women-G-SE / Editorial Board / Dept [in Spanish]. Contenido. PubliCE; 2010.

11. Seo BD, Yun YD, Kim HR, Lee SH. Effect of 12-Week Swiss Ball Exercise Program on Physical Fitness and Balance Ability of Elderly Women. Journal of Physical Therapy Science. 2012; 24(1):11-15. https://doi .org/10.1589/jpts.27.11 https://doi.org/10.1589/jpts.24.11

12. Behm DG, Colado Sanchez JC. Instability Resistance Training Across the Exercise Continuum. Sports Health. 2013; 5(6):500-503. https://doi.org/10.1177/1941738113477815 PMid:24427423 PMCid:PMC3806173

13. Nicholson VP, McKean MR, Burkett BJ. Low-Load HighRepetition Resistance Training Improves Strength and Gait Speed in Middle-Aged and Older Adults. Journal of Science and Medicine in Sport. 2015; 18(5):596-600. https://doi.org/10.1016/j.jsams.2014.07.018 PMid:25154701

14. Nicholson VP, McKean MR, Slater GJ, Kerr A, Burkett BJ. LowLoad Very High-Repetition Resistance Training Attenuates Bone Loss at the Lumbar Spine in Active Post-Menopausal Women.CalcifiedTissueInternational.2015;96(6):490-499. https://doi.org/10.1007/s00223-015-9976-6 PMid:25772806

15. Bemben D, Bemben M. Dose-Response Effect of 40 Weeks of Resistance Training on Bone Mineral Density in Older Adults. Osteoporosis International. 2011; 22(1):179-186. https://doi.org/10.1007/s00198-010-1182-9 PMid:20195844

16. Johnson BL, Nelson JK. Practical Measurements for Evaluation in Physical Education. Edina, Minnesota: Burgess Pub. 1969.

17. Sheikholeslamivatani D, Rezaei F. The Effect of 8 Weeks Resistance Training on Bone Mass Density in Postmenopausal Women with Type 2 Diabetes [in Persian]. Journal of Ilam University of Medical Sciences.
2015; 23(4):10-19.

18. Ahlborg HG, Johnell O, Turner $\mathrm{CH}$, Rannevik G, Karlsson MK. Bone Loss and Bone Size After Menopause. New England Journal of Medicine. 2003; 349(4):327-334. https: / / doi.org/10.1056/NEJMoa022464 PMid:12878739

19. Chin D, Park J, Yoon Y, Kuh S, Jin B, Kim K, et al. Prevalence of Osteoporosis in Patients Requiring Spine Surgery: Incidence and Significance of Osteoporosis in Spine Disease. Osteoporosis International. 2007; 18(9):1219-1224. https://doi.org/10.1007/s00198-007-0370-8 PMid:17387420

20. Oğuz H, Levendoğlu F, Öğün TC, Tantuğ A. Loading is More Effective Than Posture in Lumbar Spinal Stenosis: A Study With a Treadmill Equipment. European Spine Journal. 2007; 16(7):913-918. https://doi.org/10.1007/s00586-007-0317-y PMid:17273837 PMCid:PMC2219665

21. Kerr D, Ackland T, Maslen B, Morton A, Prince R. Resistance Training Over 2 Years Increases Bone Mass in Calcium-Replete Postmenopausal Women. Journal of Bone and Mineral Research. 2001; 16(1):175-181. https://doi.org/10.1359/jbmr.2001.16.1.175 PMid:11149482

22. Maddalozzo G, Snow C. High Intensity Resistance Training: Effects on Bone in Older Men and Women. Calcified Tissue International. 2000; 66(6):399-404. https://doi.org/10.1007/s002230010081 PMid:10821873

23. Vincent A, Riggs BL, Atkinson EJ, Oberg AL, Khosla S. Effect of Estrogen Replacement Therapy on Parathyroid Hormone Secretion in Elderly Postmenopausal Women. Menopause. 2003; 10(2):165-171. https://doi.org/10.1097/00042192-200310020-00009 PMid:12627043

24. Roghani T, Torkaman G, MovassegheS, Hedayati M, Goosheh B, Bayat N. Effects of Short-Term Aerobic Exercise With and Without External Loading on Bone Metabolism and Balance in Postmenopausal Women With Osteoporosis. Rheumatology International. 2013; 33(2):291-298. https://doi.org/10.1007/s00296-012-2388-2 PMid:22441962

25. Martyn-St James M, Carroll S. A Meta-Analysis of Impact Exercise on Postmenopausal Bone Loss: The Case for Mixed Loading Exercise Programmes. British Journal of Sports Medicine. 2009; 43(12):898-908. https://doi.org/10.1136/bjsm.2008.052704 PMid:18981037

26. Watson SL, Weeks BK, Weis LJ, Harding AT, Horan SA, Beck BR. High-Intensity Resistance and Impact Training 
Improves Bone Mineral Density and Physical Function in Postmenopausal Women With Osteopenia and Osteoporosis: The LIFTMOR Randomized Controlled Trial. Journal of Boneand Mineral Research. 2018;33(2):211-220. h ttps://doi.org/10.1002/jb m r. 3284 PMid:28975661

27. Smith EL, Gilligan C, McAdam M, Ensign CP, Smith PE. Deterring Bone Loss by Exercise Intervention in Premenopausal and Postmenopausal Women. Calcified Tissue International. 1989; 44(5):312-321. https: / / d o i.org/10.1007/B F02556310 PMid:2496902

28. Marques EA, Mota J, Viana JL, Tuna D, Figueiredo $P_{,}$ Guimarães JT, et al. Response of Bone Mineral Density, Inflammatory Cytokines, and Biochemical Bone Markers to a 32-Week Combined Loading Exercise Programme in Older Men and Women. Archives of Gerontology and Geriatrics. 2013; 57(2):226-233. https://doi.org/10.1016/j.archger.2013.03.014 PMid:23623588

29. Frost HM. Bone "Mass" and the "Mechanostat": A Proposal. The Anatomical Record. 1987; 219(1):1-9. https://doi.org/10.1002/ar. 1092400102 https://doi.org/10.1002/ar. 1092190104 PMid:3688455

30. Turner $\mathrm{CH}$. Homeostatic Control of Bone Structure: An Application ofFeedbackTheory. Bone.1991;12(3):203-217. https://doi.org/10.1016/8756-3282(91)90043-I

31. Barbat-Artigas S, Rolland $\mathrm{Y}$, Cesari $\mathrm{M}$, Abellan van
Kan G, Vellas B, Aubertin-Leheudre M. Clinical Relevance of Different Muscle Strength Indexes and Functional Impairment in Women Aged 75 Years and Older. Journals of Gerontology Series A: Biomedical Sciences and Medical Sciences. 2012; 68(7):811-9. https: / / doi.org/10.1093/gerona/gls 254 PMid:23262030

32. Holviala J, Kraemer W, Sillanpää E, Karppinen $H$, Avela J, Kauhanen A, et al. Effects of Strength, Endurance and Combined Training on Muscle Strength, Walking Speed and Dynamic Balance in Aging Men. European Journal of Applied Physiology. 2012; 112(4):1335-47. https://doi.org/10.1007/s00421-011-2089-7 PMid:21796409

33. Granacher U, Lacroix A, Muehlbauer T, Roettger K, Gollhofer A. Effects of Core Instability Strength Training on Trunk Muscle Strength, Spinal Mobility, Dynamic Balance and Functional Mobility in Older Adults. Gerontology. 2013; 59(2):105-113. https: / / d o i.org/10.1159/000343152 PMid:23108436

34. Gomes RM, Junior MDF, Francisco FA, Moreira VM, de Almeida DL, Saavedra LPJ, et al. Strength Training Reverses Ovariectomy-Induced Bone Loss and Improve Metabolic Parameters in Female Wistar Rats. Life Sciences. 2018; 213:134-141. https://doi.org/10.1016/j.Ifs.2018.10.032 PMid:30343128 